\title{
Malignant Mesothelioma
}

National Cancer Institute

\section{Source}

National Cancer Institute. Malignant Mesothelioma. NCI Thesaurus. Code C4456.

A malignant neoplasm of the pleura or peritoneum, arising from mesothelial cells. It is associated with exposure to asbestos. 